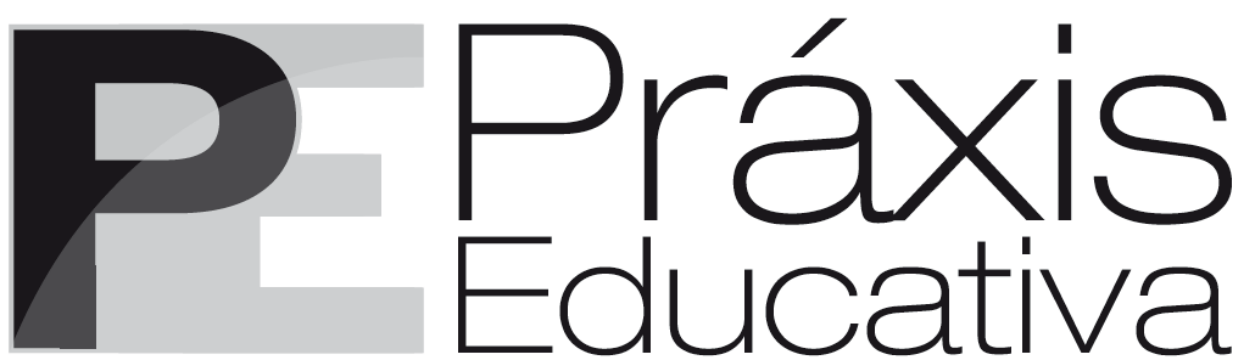

ISSN 1809-4309 (Versão online)

DOI: 10.5212/PraxEduc.v.11i3.0011

\title{
Currículo, avaliação e a constituição do sujeito docente
}

\section{Curriculum, evaluation and the constitution of the teaching subject}

\section{Currículo, evaluación y la constitución del sujeto docente}

\author{
Gabriela Pereira da Cunha Lima*
} Cláudio Lúcio Mendes**

\begin{abstract}
Resumo: $\mathrm{O}$ presente artigo analisa de modo articulado: a. o dispositivo curricular do Estado de Minas Gerais - Conteúdos Básicos Comuns (CBC) - e b. o dispositivo avaliativo a ele atrelado - Sistema Mineiro de Avaliação da Educação Pública (SIMAVE) a partir da compreensão de que as práticas neoliberais presentes no Estado e na sociedade enquadram o currículo e a avaliação sob a ótica da economia. O viés de análise toma o neoliberalismo como uma forma de governo no sentido foucaultiano, ou seja, que produz processos de subjetivação sobre as populações docentes da rede pública estadual de Minas Gerais. Desse modo, o neoliberalismo usa a educação de forma interessada na produção do sujeito para o mercado, como um importante mecanismo do Capital Humano. Seguindo essa trilha teóricometodológica, investigamos empiricamente as mudanças em curso expressas em documentos oficiais da Secretaria de Estado de Educação de Minas Gerais (especialmente relacionados ao $\mathrm{CBC}$ e ao SIMAVE). Os resultados apontam o CBC como uma proposta sintonizada com o Choque de Gestão do governo de estado de 2003 a 2014 que coloca a educação do estado de Minas Gerais sob mecanismos de regulação gerencial e de resultados, ambos a favor da economia. Concluímos que a partir da articulação entre o CBC e o SIMAVE atuam práticas de mercado gerenciais e performáticas por meio de uma série de poderes e saberes que a ela estão associados, tornando as propostas curriculares supostamente indissociáveis dessas práticas e dos processos de subjetivação dos docentes.
\end{abstract}

Palavras-chave: Currículo. Avaliação. Neoliberalismo.

\begin{abstract}
This paper analyzes in an articulated manner: a. the Minas Gerais State curriculum - Common Basic Content (CBC, Brazilian Portuguese abbreviation) - and b. the evaluation guidelines linked to it Public Education Evaluation System of Minas Gerais (SIMAVE, Brazilian Portuguese abbreviation) from the understanding that neoliberal practices frame the curriculum and the evaluation within the economy perspective. The analysis approach takes neoliberalism as a government system in the Foucauldian sense, that is, one which produces processes of subjectivation on the teaching population in the State education system in Minas Gerais. Therefore, neoliberalism uses education aiming at preparing the individuals to the market, as an important mechanism of the Human Capital. Following this theoretical-methodological route, we investigated empirically the ongoing changes expressed in the official documents issued by the

\footnotetext{
* Professora do Departamento de Educação da Universidade Federal de Ouro Preto (UFOP). E-mail: <gabiplima@yahoo.com.br>.

** Professor do Departamento de Educação da Universidade Federal de Ouro Preto (UFOP). E-mail: $<$ claudio.ufop@yahoo.com.br>.
} 
Minas Gerais State Education Secretariat (mainly those related to the CBC and SIMAVE). The results show the CBC as a proposal which is in tune with the Management Chock of the State Government from 2003 to 2014 which places the education in the State of Minas Gerais under regulating mechanisms of management and results, both in favor of the economy. The conclusion points to the articulation between $\mathrm{CBC}$ and SIMAVE acting as managerial and performing market practices through a number of powers and knowledges associated to it, making the curriculum proposal supposedly inseparable from such practices.

Keywords: Curriculum. Evaluation. Neoliberalism.

Resumen: El artículo analiza de modo articulado: a. El dispositivo curricular del estado de Minas Gerais Contenidos Básicos Comunes (CBC) - y b. el dispositivo evaluativo involucrado - Sistema Mineiro de Avaliação da Educação Pública (SIMAVE) a partir de la comprensión de que las prácticas neoliberales encuadran el currículo y la evaluación por la óptica de la economía. La ruta del análisis se utiliza del neoliberalismo como forma de gobierno en el sentido foucaultiano, o sea, que produce procesos de subjetivación sobre las poblaciones docentes de la red pública estadual de Minas Gerais. De ese modo, el neoliberalismo usa la educación de forma interesada en la producción de sujeto para el mercado, como un importante mecanismo de Capital Humano. En este mismo segmento teórico-metodológico investigamos empíricamente los cambios en la trayectoria expresados en documentos oficiales de la Secretaria de Estado de Educação de Minas Gerais (especialmente relacionados al CBC y al SIMAVE). Los resultados conllevan al CBC como una propuesta en sintonía con el Choque de Gestión de gobierno de estado de 2003 a 2014 que dispone la educación del estado de Minas Gerais en influencias de mecanismos de regulación gerencial e de resultados, ambos en favor da economía. Concluimos que a partir da articulación entre o CBC e o SIMAVE actúan prácticas de mercado gestionables y performácticas por medio de una serie de poderes y saberes que a ella están asociadas, tornando las propuestas curriculares supuestamente indisociables des esas prácticas.

Palabras clave: Currículo. Evaluación. Neoliberalismo.

\section{Introdução}

Neste trabalho, de maneira mais ampla, problematizamos os processos de subjetivação docente postos em ação pelos dispositivos curriculares e avaliativos nas reformas neoliberais. Mas o que queremos dizer quando nos referimos às propostas curriculares e aos sistemas de avaliação como dispositivos? Dispositivo, neste artigo, é tomado como uma ferramenta conceitual e metodológica criada por Foucault que nos ajuda a analisar o poder a partir dos mecanismos de dominação e controle, para além do edifício jurídico dos aparelhos de Estado. É, "por definição, de natureza heterogênea: trata-se tanto de discursos quanto de práticas, de instituições quanto de táticas moventes" (REVEL, 2005, p. 39). Podemos concebê-lo como formas de se exercer o poder, apoiadas em instrumentos de saber, produzindo efeitos de objetivação, sujeição e subjetivação.

O dispositivo, portanto, está sempre inscrito em um jogo de poder, estando sempre, no entanto, ligado a uma ou a configurações de saber que dele nascem, mas que igualmente o condicionam. É isto, o dispositivo: estratégias de relações de força sustentando tipos de saber e sendo sustentadas por eles. (FOUCAULT, 1992, p. 139).

De modo mais específico, analisamos a articulação desses dispositivos na última reforma educacional promovida pelo governo de estado de Minas Gerais (2003-2014), denominada de Conteúdos Básicos Comuns (CBC) e a versão avaliativa a ela atrelada: o Sistema Mineiro de Avaliação da Educação Pública (SIMAVE). Tanto de maneira ampla como específica, partimos do princípio de que as reformas educacionais movidas pelos governos neoliberais são constituídas por diferentes elementos, tais como mudanças no âmbito da legislação, dos 
mecanismos de financiamento, das políticas de formação de professores e de avaliação, da gestão escolar, dentre outras. Com a implantação de novos dispositivos curriculares, os governos promovem mudanças amplas e profundas que visam à instituição de distintos processos de subjetivação de professores, gestores e alunos.

Além disso, os contextos escolares de produção dos currículos recebem o fluxo de propostas produzidas em outros contextos de influência (casas legislativas, secretarias de educação, grupos de teóricos curriculares) concretizadas em políticas educacionais semelhantes e levadas a cabo por partidos políticos que seguem orientações supostamente distintas. A estreita relação constituída nos jogos de governamentalidade entre os elementos em ação nos contextos de influência produzem comunidades epistêmicas que dão sentido de verdade às políticas curriculares (BALL, 1998). Estas valorizam a avaliação como garantia de qualidade, e a padronização de currículos circula e é legitimada por intelectuais e técnicos (nem sempre profissionais da educação).

A equação que legitima as políticas curriculares neoliberais globalizadas parece, à primeira vista, bastante óbvia e simples: é preciso pensar a escola como parte de um mercado educacional (ainda que público) regido pelas mesmas regras que estruturam o mundo empresarial. Tendo isso como princípio, as escolas aumentarão o desempenho e a qualidade dos serviços oferecidos (BALL, 2001). Finalmente, os sujeitos formados em tais escolas mais eficazes contribuirão para o aumento da competitividade econômica local e internacional. Os currículos devem potencializar tal equação, à medida que se alinham cada vez mais às demandas do mercado e da economia. Ao mesmo tempo, criam um conjunto de conteúdos supostamente comuns a todos, que devem ser incorporados pelas escolas para alcançar um bom desempenho no ranking produzido a partir das avaliações externas (BALL, 1998). O trabalho docente passa então a ser pensado em função do posicionamento da escola na arena mercadológica, uma vez que, por meio dos resultados obtidos nas avaliações as escolas desvalorizam-se ou valorizam-se, atraindo ou repelindo o "cidadãocliente" (HYPÓLITO; IVO, 2013).

Esse conjunto de discursos e práticas que incidem sobre a Educação tem uma função produtiva e formam sistematicamente os objetos de que falam. Por um lado, novos professores, novos alunos, novos gestores, uma nova forma de pensar e organizar o trabalho educativo sob a égide da competitividade e da eficiência: esse é o quadro que as políticas educacionais empreendidas pelos Estados neoliberais pretendem configurar. Por outro, muitas vezes à tentativa de padronização e controle das práticas docentes, os professores e as escolas respondem com um elogio à diferença, e trabalham pela "variação de sentidos, pela multiplicação das forças, pela disseminação daquilo que aumenta a potência de existir, pela proliferação dos afetos felizes" (MEYER; PARAÍSO, 2012, p. 32). Dito de outra maneira, resistem, buscam alternativas, elaboram estratégias para ressignificarem a configuração neoliberal das políticas educacionais recentes em seus cotidianos. Assim, entendemos que os professores e as escolas não participam massiva e docilmente desses processos, mesmo que sejam massificadores e docilizadores.

Os mecanismos regulatórios dos dispositivos curriculares não são artefatos neutros, meramente científicos ou produzidos fora das relações de poder. Ao contrário, esses dispositivos são construídos em campos contestados, nos quais diferentes visões sobre a educação estão em disputa pela produção de sentidos, de verdades construtoras da realidade e que nos governam e nos constrangem. Currículos são, dessa forma, embebidos em "atos de poder, o poder de significar, de criar sentidos" e torná-los naturalizados (LOPES; MACEDO, 2011, p. 40). Se os dispositivos curriculares são atos de poder, instrumentos e produtos da disputa pela instauração de regimes de verdade e conduta, no tempo presente eles têm sido fortemente marcados pelo

Práxis Educativa, Ponta Grossa, p. 714-735, v. 11, n. 3, set./dez. 2016 Disponível em: <http://www.revistas2.uepg.br/index.php/praxiseducativa> 
pensamento neoliberal, contribuindo - por meio de seus discursos, seus mecanismos e suas práticas - para o fortalecimento dessa racionalidade.

Para desenvolver as discussões e análises em torno da subjetivação docente constituída por mecanismos presentes no CBC (como dispositivo curricular) e no SIMAVE (como dispositivo avaliativo), na próxima seção, apresentamos a governamentalidade como uma ferramenta analítica. A seguir, nos atemos à reforma curricular e à centralidade dos processos avaliativos nas políticas educacionais neoliberais. Analisamos logo depois, o SIMAVE, atentos aos contextos de sua influência e produção, identificando de modo específico as práticas que se dirigem diretamente aos professores e que intentam controlar e modificar suas condutas docentes. Antes de concluirmos, apresentamos algumas ponderações em torno da relação direta entre os dispositivos em questão e a constituição do sujeito docente da rede pública mineira.

\section{A governamentalidade como ferramenta analítica}

À medida que fomos nos aproximando dos autores com os quais dialogamos durante o percurso investigativo do qual resultou este texto, especialmente Michel Foucault e Stephen Ball, compreendemos que as mudanças e demandas que nos atravessavam no contexto de Minas Gerais deviam ser interpretadas como parte de um fenômeno histórico mais amplo denominado de governamentalidade neoliberal. A emergência dessa forma de governar - em sua razão política e suas formas técnicas e tecnológicas de controle - produz efeitos no campo da Educação. Não por acaso, as reformas educacionais promovidas em países como Brasil, Espanha, Inglaterra, Estados Unidos e Argentina apresentam tantas similitudes (MOREIRA, 1996), e os mesmos especialistas dali estão a ditar caminhos acolá.

Autores têm trabalhado a importância dos fenômenos de recontextualização dos discursos e das políticas neoliberais em contextos específicos, atentando-nos para o fato de que

[...] a criação das políticas nacionais é, inevitavelmente, um processo de "bricolagem"; um constante processo de empréstimo e cópia de fragmentos e partes de ideias de outros contextos, de uso e melhoria das abordagens locais já tentadas e testadas, de teorias canibalizadoras, de investigação, de adoção de tendências e modas e, por vezes, de investimento em tudo aquilo que possa vir a funcionar. (BALL, 2001, p. 102).

Reconhecemos a pertinência de trabalhos dessa natureza, que reforçam a importância das tradições históricas, locais e regionais, nos processos de elaboração e adaptação de políticas públicas para a Educação. Além disso, buscamos identificar quais são os "aspectos comuns na diferença" (BALL, 2001, p. 103), as formas de unidade articuladas que constituem as políticas educacionais e que estão inseridas em estratégias de reformas genéricas. Tais estratégias, por sua vez, articulam um conjunto de técnicas e tecnologias políticas de modo a produzirem novos valores, novas relações e novas subjetividades nas arenas das práticas cotidianas.

Nesse sentido, propomos uma reflexão acerca de algumas características marcantes das políticas públicas para a educação promovidas pelos Estados neoliberais, especialmente em torno de seus efeitos sobre os processos de subjetivação docente. Partimos da ideia de que as práticas governamentais neoliberais tendem a enquadrar todos os objetos e sujeitos sob a ótica da economia, dilatando o campo desse tipo de análise para campos tradicionalmente considerados como não econômicos. Desse modo, mais do que simplesmente analisar em termos econômicos diferentes fenômenos sociais, os governos neoliberais agem no sentido de interferir na conduta dos indivíduos, para que também eles passem a orientar suas vidas pautados pelos preceitos do mercado. Argumentamos que, cada vez mais, somos levados a pensar sobre nós mesmos como sujeitos-empresa, empreendedores de nossa própria vida, discurso que vem atravessando a 
educação e conformando suas práticas.

Assim, como podemos pensar os efeitos do neoliberalismo sobre a educação? De que modo a profissão e a subjetividade docentes vêm sendo afetadas pelas políticas neoliberais? Como podemos nos aproximar dessas questões evitando os riscos dos discursos de celebração e denúncia? Seguindo a trilha teórico-metodológica aberta por Michel Foucault, é possível investigar empiricamente as mudanças em curso (RABINOW; ROSE, 2006), expressas em documentos oficiais da Secretaria de Estado de Educação de Minas Gerais (especialmente relacionados ao $\mathrm{CBC}$ e ao SIMAVE). Isso implica em "tomar as práticas concretas [expressas em tais documentos] como domínio privilegiado de análise" (LARROSA, 1994, p. 9), já que essas práticas sociais engendram domínios de saber, conceitos, técnicas e mesmo formas totalmente novas de sujeitos e de objetos do conhecimento (FOUCAULT, 2009).

Essa busca pelas formas praticáveis presentes no CBC e SIMAVE pode nos ajudar a compreender quais processos de subjetivação e objetivação tratam da transformação do indivíduo em sujeito e objeto do conhecimento, no caso analisado, do professor da rede pública do estado de Minas Gerais. A partir dessa perspectiva que busca entender a constituição do sujeito com base em mecanismos a proporem práticas concretas, somos levados a pensar o neoliberalismo "não como uma teoria nem como uma ideologia, menos ainda, claro, como uma maneira de a sociedade se representar; mas como uma prática, isso é, como uma 'maneira de fazer' orientada para objetivos e regulando-se por uma reflexão contínua" (FOUCAULT, 2008, p. 432). O entendemos como uma forma de governo (especialmente de Estado, mas igualmente dos outros e de si) que, por variadas e complexas maquinarias de saber-poder ${ }^{1}$, certas metas, determinados objetivos e fins específicos são planejados e propostos para serem potencialmente alcançados (FOUCAULT, 1992).

Ao pensarmos o neoliberalismo como uma razão de governo expressa por meio das mais diversas práticas, razão que é ela mesma múltipla e móvel - e que se exerce de diferentes modos nos Estados contemporâneos - provocamos um deslocamento analítico importante em relação ao pensamento político tradicional: não tomaremos o Estado neoliberal como um universal, algo que possua uma essência que deva ser buscada em todas as suas corporificações.

Em vez de partir dos universais para deles deduzir fenômenos concretos, ou antes, em vez de partir dos universais como grade de inteligibilidade obrigatória para um certo número de práticas concretas, gostaria de partir dessas práticas concretas e, de certo modo, passar os universais pela grade dessas práticas. (FOUCAULT, 2008, p. 5).

Esse modo específico de pensar pode ser tomado como uma "resposta histórica à questão filosófica sobre o modo como as coisas são constituídas" (RAJCHMAN, 1987, p. 47). Não existem condições transcendentais que presidem nossa experiência, mas emergências, "em momentos específicos, de pressupostos comuns a um corpo disseminado de pensamento e política" (ibidem). Ideias, práticas, instituições, sistemas de governo: nada disso surge graças a uma ordem cósmica, atemporal ou por obra da ação personalista de alguns sujeitos. A

\footnotetext{
1 Pensar as complexas maquinarias de saber-poder é partir do princípio que "o poder não é da ordem do consentimento; ele não é, em si mesmo, renúncia a uma liberdade, transferência de direito, poder de todos e de cada um delegado a alguns" (FOUCAULT, 1995, p. 243). Somado a isso, "ele não pesa só como uma força que diz não, mas que de fato ele permeia, produz coisas, induz ao prazer, forma saber" (ibidem, p. 8) e também se apoia em saberes (da economia, da medicina, do campo jurídico, da psicanálise). O poder "é um conjunto de ações sobre ações possíveis; ele opera sobre o campo de possibilidade onde se inscreve o comportamento dos sujeitos ativos; ele incita, induz, desvia, facilita ou torna mais difícil, amplia ou limita, torna mais ou menos provável; no limite, ele coage ou impede absolutamente, mas é sempre uma maneira de agir sobre um ou vários sujeitos ativos, e o quanto eles agem ou são suscetíveis de agir". Em síntese, "uma ação sobre ações" (ibidem, p. 243) que assume formas práticas e praticáveis de saber-poder.
}

Práxis Educativa, Ponta Grossa, p. 714-735, v. 11, n. 3, set./dez. 2016 Disponível em: <http://www.revistas2.uepg.br/index.php/praxiseducativa> 
compreensão da emergência dos fenômenos deve ser buscada nas complexas condições históricas, políticas e sociais que as tornaram possíveis.

Nessa perspectiva, devemos pensar o Estado neoliberal não como portador de uma natureza ou de uma essência, mas como

[...] o efeito, o perfil, o recorte móvel de uma perpétua estatização, ou de perpétuas estatizações, de transações incessantes que modificam, que deslocam, que subvertem, que fazem deslizar insidiosamente, pouco importa, as fontes de financiamento, as modalidades de investimento, os centros de decisão, as formas e os tipos de controle, as relações entre as autoridades locais, a autoridade central, etc. (FOUCAULT, 2008, p. 106).

Se o Estado neoliberal é esse "efeito móvel de um regime de governamentalidades múltiplas" (FOUCAULT, 2008, p. 106), então a melhor pergunta que devemos elaborar em torno dele é: como funcionam tais mentalidades de governo? Ou ainda: como tais governamentalidades se manifestam praticamente? No nosso caso, perguntamos: de que forma a governamentalidade neoliberal vem propondo subjetividades e experiências docentes no contexto da reforma mineira, especialmente por meio de seus dispositivos curriculares e avaliativos? A resposta a essa pergunta será sempre limitada pelo quadro histórico que a torna possível, e deve se atentar às políticas de governo de Estado e aos regimes de verdade que ele mobiliza e legitima: movimentos próprios à governamentalidade. Reafirmamos que os elementos trazidos pelas reformas educacionais promovem não apenas mudanças na estrutura organizacional das escolas e do trabalho docente, mas também poderosos processos de subjetivação do professor, que intentam transformá-lo no docente competitivo, pragmático e autogerido que a governamentalidade neoliberal potencializa.

\section{A Reforma curricular mineira e seus dispositivos}

As reformas educacionais movidas pelos governos neoliberais mundo afora são constituídas por diferentes elementos, tais como mudanças no âmbito da legislação, dos dispositivos de financiamento, das políticas de formação de professores e de avaliação, da gestão escolar, dentre outras (DARLING-HAMMOND; ASCHER, 2006; PETERS; MARSHALL; FITZSIMONS, 2004). Nesse contexto mundial, as políticas curriculares e os sistemas avaliativos a elas atrelados parecem assumir uma centralidade cada vez maior a partir da década de 1990, a ponto de serem analisadas como se fossem, em si, a reforma educacional (LOPES, 2004). Em todas as partes, com a implantação de novos dispositivos curriculares, os governos promovem mudanças amplas e profundas, que visam à instituição de distintas subjetividades de professores, gestores e alunos (BALL, 2002).

É especialmente por meio do currículo que a governamentalidade neoliberal deseja conduzir os sujeitos da Educação. Em diferentes dispositivos curriculares, professores, alunos, gestores e instituição escolar têm seus tempos, objetivos e resultados controlados. A estreita vinculação dos componentes curriculares aos resultados obtidos nas avaliações externas reforça e agudiza os mecanismos de controle postos em ação por intermédio do currículo (BALL, 2005).

Uma nova forma de controle sobre os professores é instaurada pelas políticas neoliberais, que, ao mesmo tempo em que constrangem a autonomia dos professores sobre seu fazer (especialmente por meio das avaliações atreladas aos currículos), também responsabilizam os docentes pelos resultados produzidos e intensificam a carga de trabalho a que estão submetidos (HYPÓLITO; VIEIRA; PIZZI, 2009). A intenção de conduzir e normalizar o trabalho dos professores é explicada na política do $\mathrm{CBC}$ da seguinte forma:

Práxis Educativa, Ponta Grossa, p. 714-735, v. 11, n. 3, set./dez. 2016 Disponível em: < http://www.revistas2.uepg.br/index.php/praxiseducativa > 
[...] a Proposta Curricular é compatível com os Parâmetros Curriculares Nacionais e se inspira em várias de suas proposições. Sua primeira contribuição é a de destacar, de modo mais claro, as ideias básicas do currículo, ou seja, aquilo que não pode deixar de ser ensinado. Além disso, esta proposta avança na descrição mais detalhada dos tópicos do Conteúdo Básico Comum, com a intenção de orientar seu ensino. (MINAS GERAIS, 2006b, p. 11).

Não só prescrever conteúdos, mas orientar também o ensino. O trecho acima ilustra uma parte do paradoxo que atravessa as políticas curriculares neoliberais. Por um lado, os docentes convivem cotidianamente com uma série de práticas que são a própria negação da autonomia docente, com a padronização das propostas curriculares para a educação pública em Minas Gerais, que é apontada como a saída mais viável de melhoria dos índices educacionais e pautada em uma proposta nacional (os Parâmetros Curriculares Nacionais). Por outro, um discurso da autonomia que convida os professores e as escolas a criarem e flexibilizarem, como está expresso nos cadernos do CBC:

[...] a Proposta Curricular se assenta nas bases de um currículo flexível, capaz de se ajustar à realidade de cada escola, de cada região do Estado e às preferências e estilos de ensino dos professores. Entretanto, ela aponta para alguns conteúdos [o $\mathrm{CBC}]$ que, por sua relevância, são considerados essenciais. [...]. O CBC irá compor a matriz de competências básicas para a avaliação do sistema público de ensino em Minas Gerais. Além dos Conteúdos Básicos Comuns, esta Proposta Curricular sugere Conteúdos Complementares, que devem ser examinados pela equipe de profissionais de cada escola para compor seu projeto de ensino para a disciplina. (MINAS GERAIS, 2006b, p. 11).

A proposta afirma se assentar nas bases de um currículo flexível, mas apresenta os conteúdos e as competências a serem desenvolvidos prioritariamente. Deduzimos que tais prioridades devem estar intimamente relacionadas ao Projeto Político Pedagógico de cada escola, fruto da construção coletiva entre alunos, professores, coordenadores, gestores e comunidade escolar. A autonomia docente deve, pela definição sobre o que e como ensinar, permitir aos professores incrementar seu poder discricionário e exercer parte do controle sobre os fins sociais e políticos da educação. A produção de currículos ocorrida em ambientes externos à escola configura-se, nesse sentido, em um instrumento de controle disciplinar do trabalho educativo e da identidade docente.

O perigo da imposição exógena dos objetivos escolares é a proletarização do ofício; um novo modo de exercício da docência, mais afeito à execução que à elaboração, mais afeito à ação que à reflexão. Ao mesmo tempo em que reforça o poder de especialistas, a padronização do trabalho docente, por meio dos currículos oficiais, conduz a conduta dos professores no sentido das metas traçadas pelos governos. Essas metas são expostas aos pais e alunos para que esses também sejam agentes de controle, ficando atentos se tais metas estão sendo cumpridas pelos docentes e pelas escolas Tal exposição tem a finalidade de colocar pais e alunos como agentes de conduta da conduta dos professores nos ambientes escolares, aproximando e afinando os mecanismos de controle externos propostos pelos governos neoliberais aos processos de autocontrole dos docentes requeridos pelos mesmos governos. Com base no atrelamento do CBC aos resultados obtidos nas avaliações SIMAVE, e destes ao pagamento de bonificações aos professores e também ao posicionamento das escolas no ranking educacional do estado, os mecanismos de controle do trabalho docente por meio dos currículos se refinam e se reforçam mutuamente. ${ }^{2}$

\footnotetext{
$2 \mathrm{O}$ processo de proletarização em Minas Gerais é bem complexo. Baseado no argumento da urgência de enfrentar uma grave crise fiscal e administrativa - argumento muito em voga na governamentalidade neoliberal mundo afora -, o governo da gestão de Aécio Neves (2003-2006) lançou o programa intitulado "Choque de Gestão". Em linhas
}

Práxis Educativa, Ponta Grossa, p. 714-735, v. 11, n. 3, set./dez. 2016 Disponível em: <http://www.revistas2.uepg.br/index.php/praxiseducativa> 
Podemos pensar que a política curricular do CBC e a estrutura avaliativa a ele associada atuam sobre os professores exercendo um poder disciplinar e um biopoder (FOUCAULT, 2000). $\mathrm{O}$ exercício do poder disciplinar se faz por meio de técnicas e discursos que se dirigem aos docentes para torná-los sujeitos dóceis e manipuláveis. No caso da reforma educacional analisada neste texto, o dispositivo do exame atua de modo intenso - por tentar identificar quem está aprendendo, quem não está e por propor como os professores devem atuar nos dois casos - e performático - por constituir uma "tecnologia, uma cultura e um método de regulamentação que emprega julgamentos, comparações e demonstrações como meios de controle, atrito e mudança" (BALL, 2005, p. 543).

Por sua vez, o biopoder, forma característica do poder estatal, não se dirige aos corpos individuais dos professores, mas ao corpo social e coletivo, ao corpo das populações docentes, cujas condutas pretende controlar e administrar. Vale lembrar que o poder, na perspectiva adotada neste trabalho, não apenas reprime, mas, sobretudo, produz realidades. O professor produzido pela biopolítica neoliberal deve ser maleável, pró-ativo, inventivo. Aí reside uma espécie de paradoxo que encerra o trabalho docente sob os governos neoliberais: querem-no enformado, obediente, fiel aos programas curriculares e perseguidor dos resultados e das metas estabelecidos; ao mesmo tempo, querem-no dinâmico, flexível, adaptável, criativo. É o jogo da liberdade da governamentalidade neoliberal posto em ação: devemos ser autônomos, desde que essa autonomia se inscreva em campos de escolha predeterminados.

Stephen Ball (2005) afirma que os sistemas de avaliação externa produzidos sobre a escola são tecnologias centrais ao controle do trabalho docente. No caso de Minas Gerais, os Conteúdos Básicos Comuns estão intimamente integrados ao dispositivo avaliativo articulado pelo governo. Um novo sentido para o currículo emerge das políticas neoliberais: "a reconversão do currículo de um sistema centrado no ensino para um sistema centralizado na avaliação" (TERIGI, 1996, p. 177). Cada vez mais, aquilo que deve ser ensinado é definido em função do que será avaliado. "A avaliação estabelecida de forma homogênea pelo poder [estatal] para todos os sujeitos em idade escolar converte-se no verdadeiro curriculum" (TERIGI, 1996, p. 178, grifo na obra). Esse deslocamento do currículo em direção às avaliações externas está relacionado à redefinição do papel do Estado na prestação do serviço educativo. O Estado se exterioriza no que se refere à prestação de serviços. Cada vez mais, torna-se um controlador dos efeitos dessa prestação, um regulador do mercado educativo, colocando a avaliação em um papel central para o funcionamento desses mecanismos de controle.

\section{A centralidade da avaliação nas políticas educacionais neoliberais}

A governamentalidade neoliberal que orientou a reforma do Estado brasileiro na década de 1990 também dá forma à Lei de Diretrizes e Bases da Educação Nacional (LDB/1996). A Lei atribui à União a responsabilidade pela criação de dispositivos avaliativos do desempenho das escolas, fortemente recomendados por organismos internacionais como o Banco Mundial (BM), o Fundo Monetário Internacional (FMI) e a Comissão para a América Latina e Caribe (CEPAL). Nesse contexto, estrutura-se um controle da educação por meio do estabelecimento de metas e

gerais, o programa se comprometia a promover a modernização da administração, a racionalização de gastos, o monitoramento e avaliação das ações e dos resultados das intervenções governamentais. O Acordo de Resultados, mecanismo central para o Choque, foi um contrato de gestão que buscou alinhar as instituições e os professores às metas estabelecidas pelo governo. No contexto do Choque, os sujeitos e as instituições que alcançam os resultados estabelecidos no Acordo são premiados por seu mérito; os que fracassam são sancionados por seu insucesso. Assim, o processo de responsabilização docente e de sua proletarização se mostra em todo o seu esplendor: seu valor como profissional é proporcional à contribuição que ele dá à performatividade de sua unidade e às metas de governo.

Práxis Educativa, Ponta Grossa, p. 714-735, v. 11, n. 3, set./dez. 2016 Disponível em: < http://www.revistas2.uepg.br/index.php/praxiseducativa > 
padrões de rendimento, centralizado pela União, cuja primeira experiência contemporânea em nível nacional ocorrera com a criação do Sistema Nacional de Avaliação da Educação Básica (SAEB). Não por acaso, o ministro da educação à época, Paulo Renato de Souza, foi elogiado pelo presidente do Banco Mundial (instituição em que trabalhou durante um período de sua vida como consultor) por sua atuação e seu alinhamento às demandas dessa agência (ALTMANN, 2002, p. 80). De acordo com Torres (1998), o pacote de reformas educacionais proposto pelo Banco Internacional para a Reconstrução e Desenvolvimento (braço financeiro do BM) aos países da África e da América Latina contém uma série de elementos comuns, articulados em torno de objetivos mensuráveis, incremento das privatizações e do financiamento pautado nos resultados alcançados pelos sistemas nas avaliações em larga escala.

A internacionalização dos processos decisórios, bem como a influência de determinados organismos internacionais sobre a conduta dos Estados, são fenômenos que emergem na segunda metade do século XX e adquirem contornos específicos no que se refere à educação a partir dos anos 1990. Nos documentos produzidos por tais organismos nesse período, a importância da criação de dispositivos avaliativos nacionais em larga escala é enfaticamente apresentada. A título de ilustração podemos citar a Conferência Mundial de Educaşão para Todos, ocorrida em Jomtien, na Tailândia, patrocinada, dentre outros, pelo Banco Mundial. Na declaração resultante dessa conferência foi estabelecido o compromisso dos países participantes em definir "[...] níveis desejáveis de aquisição de conhecimentos e implantar sistemas de avaliação de desempenho" (DECLARAÇÃO, 1991, p. 5). Tais sistemas de avaliação são considerados "vitais" para a construção de uma base de conhecimentos e informações acerca dos sistemas educacionais nacionais e tomados, a partir de então, como condição necessária para o planejamento e a gestão da Educação Básica.

A ação do Banco Mundial, como afirmamos anteriormente, foi preponderante para a conformação do sistema avaliativo brasileiro. O Banco demandava, ao longo dos anos 1990, uma análise dos impactos do Projeto Nordeste, realizado com base no acordo entre o MEC e o Banco Internacional para Reconstrução e Desenvolvimento (BIRD). O Projeto contemplou os nove estados nordestinos (Alagoas, Bahia, Ceará, Maranhão, Paraíba, Pernambuco, Piauí, Rio Grande do Norte e Sergipe), sendo constituído por ações que se destinavam à melhoria da qualidade do ensino nas primeiras séries do Ensino Fundamental das redes estaduais e municipais de educação, propondo a integração entre estados e municípios e a mudança no padrão de gestão da educação pública. É considerado um dos mais importantes projetos financiados pelo Banco Mundial no Brasil, tendo movimentado, ao longo de sua execução, mais de 400 milhões de dólares. ${ }^{3}$

No contexto das recentes políticas neoliberais, as primeiras experiências de avaliação em larga escala no Brasil ocorreram em 1988, com a criação do Sistema Nacional de Avaliação do Sistema Público (SAEP), cujas primeiras provas foram aplicadas em caráter de teste nos estados do Rio Grande do Norte e Paraná. Em 1990, o SAEP inicia seu primeiro ciclo em todo o território nacional, desenvolvido de forma descentralizada pelos estados e municípios. De acordo com Werle (2011, p. 774), os ciclos do SAEP que aconteceram entre 1990 e 1995 foram marcados pela "participação ativa de professores e técnicos das Secretarias de Educação, [...] tanto no tratamento como na análise dos dados, conforme princípio de descentralização operacional e organizativa".

Entretanto, a partir de 1995, o SAEP, agora nomeado Sistema de Avaliação da Educação Básica (SAEB) assumiu um novo perfil, marcado pela terceirização de operações técnicas e pela restrição do papel do MEC à definição dos objetivos gerais norteadores do Sistema. Os professores das universidades, chamados pelo Instituto Nacional de Estudos Pedagógicos

${ }^{3}$ Disponível em: <http://web.worldbank.org>. Acesso em: 07 jul. 2015.

Práxis Educativa, Ponta Grossa, p. 714-735, v. 11, n. 3, set./dez. 2016 Disponível em: < http://www.revistas2.uepg.br/index.php/praxiseducativa > 
(INEP) a participar dos primeiros ciclos do SAEP, foram excluídos do processo de discussão e elaboração das avaliações. Podemos dizer que, em meados dos anos 1990, "ocorre uma reordenação na avaliação em larga escala da Educação Básica na direção de uma centralização de decisões na União" (WERLE, 2011, p. 775).

O distanciamento entre as esferas de monitoramento, gestão e execução das políticas educacionais, que caracteriza o funcionamento do SAEP, vai se repetir nos modelos de avaliação adotados por alguns estados que, a partir dos anos 1990, "deflagraram a constituição de sistemas próprios de avaliação, com o objetivo de produzir um número ainda maior de informações e subsidiar a formulação de políticas públicas destinadas à melhoria do ensino" (MINAS GERAIS, 2009, p. 44). Nesse sentido,

[...] a introdução de sistemas de avaliação da educação e do desempenho docente é crucial para essa regulação por parte do Estado, que passa a controlar e a avaliar desde longe, por meio da contratação de terceiros para realizar a avaliação externa considerada como prestação de contas à sociedade civil (accountability). Tais modelos gerenciais são baseados na qualidade e no mérito e os problemas da educação ficam reduzidos a problemas técnico-gerenciais. (HYPÓLITO, 2010, p. 1339).

É importante observar que, nesse mesmo contexto de emergência das avaliações externas em larga escala, surgem também currículos obrigatórios que devem servir como referência aos testes aplicados. Desse modo, podemos afirmar que a avaliação sob o governo dos Estados neoliberais gerencialistas, vem funcionando como um elemento definidor de sentido, endereçando-se ao currículo e suas diretrizes. Em Minas Gerais, a instituição dos Conteúdos Básicos Comuns se fez acompanhar pela criação de um sistema integrado de avaliação que, supostamente, pela sua ação, identificará as escolas "boas" e as escolas "ruins". Isso passa a possibilitar aos pais (aqui encarados como "consumidores" do produto educação) duas coisas: 1) fazer a melhor escolha para seus filhos em termos de qual escola matriculá-los; 2) participarem do controle do trabalho docente proposto pelo governo. Nessa lógica, aparece a ideia de que as escolas de baixo desempenho tenderão "naturalmente" a desaparecer - bem como os professores ruins -, enquanto as escolas bem-sucedidas serão gratificadas e fortalecidas pelo governo - bem como os bons professores (PARAÍSO; SANTOS, 1996). De acordo com a Secretaria de Estado da Educação (SEE/MG),

[...] a importância dos CBCs justifica tomá-los como base para a elaboração da avaliação anual do Programa de Avaliação da Educação Básica (PROEB), para o Programa de Avaliação da Aprendizagem Escolar (PAAE) e para o estabelecimento de um plano de metas para cada escola. O progresso dos alunos, reconhecido por meio dessas avaliações, constitui a referência básica para o estabelecimento de sistema de responsabilização e premiação da escola e de seus servidores. (MINAS GERAIS, 2007, p. 9).

Mas os dados produzidos por meio de tais avaliações também servem como referência para as ações do governo acerca da população escolar, de modo que "os saberes construídos por diferentes instituições e experts, com base em dados coletados, em registros, em comparações, subsidiam decisões administrativas para manter e otimizar as características desejáveis da população" (TRAVERSINI; BELLO, 2009, p. 137).

O dispositivo avaliativo de Minas Gerais está articulado em torno do SIMAVE, do qual fazem parte o PROEB, o Programa de Avaliação da Alfabetização (PROALFA) e o PAAE. Sob o lema "avaliar para avançar", o SIMAVE foi instituído pela Resolução no. 14, de 3 de fevereiro de 2000, durante o governo de Itamar Franco. No documento produzido pela Secretaria de Educação naquele contexto, intitulado "Escola Sagarana: educação para a vida com dignidade e esperança", fica estabelecido o objetivo de "avaliar a qualidade do ensino em todos os níveis e

Práxis Educativa, Ponta Grossa, p. 714-735, v. 11, n. 3, set./dez. 2016 Disponível em: <http://www.revistas2.uepg.br/index.php/praxiseducativa > 
modalidades, mediante exames do rendimento dos alunos, metodologias de controle e

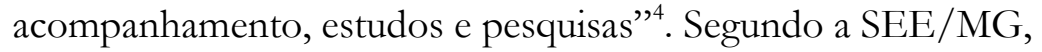

[...] as avaliações realizadas pelo SIMAVE buscam aferir todas as dimensões do sistema educacional da rede pública estadual. Elas analisam os resultados alcançados em sala de aula, na escola e no sistema; na ação docente, na gestão escolar e nas políticas públicas para a Educação; no nível de aprendizagem, na alfabetização e nos conteúdos básicos do ensino fundamental e médio (SEE/MG). ${ }^{5}$

Os resultados trazidos pelos programas que compõem o SIMAVE servem para a elaboração dos Programas de Intervenção Pedagógica (PIP) ${ }^{6}$, cujo objetivo é "sanar" os problemas identificados pela avaliação do SIMAVE. Vale dizer que os planos do PIP são aplicados e monitorados por técnicos e analistas externos à escola, especialistas chamados a resolver aquilo que os professores supostamente não sabem (ou não querem) fazer. Mais uma vez, estamos diante de uma forma de governo que desqualifica os saberes construídos na prática dos professores e legitima os saberes instrumentais de especialistas alçados à posição de interlocutores privilegiados para a elaboração de políticas educacionais.

O discurso do governo parece não considerar relevante a perspectiva dos professores para a identificação de demandas significativas à rede estadual de ensino. Embora o trabalho docente seja direta e indiretamente examinado nas avaliações de larga escala, as políticas educacionais neoliberais atuam de modo centralizado, desconhecendo os anseios, os desejos e as especificidades dos professores às quais se dirigem.

Nas avaliações da Educação Básica, o professor é posto como alvo da análise, muito mais que qualquer outro ponto, já que, para o senso comum, e logo, para a "opinião pública", é ele o grande responsável pelos resultados de seus alunos e sua instituição, sendo menos consideradas dimensões como modalidades de gestão, infraestrutura, disponibilidade de material, aspectos políticos, dentre outros. (DAMETTO, 2012, p. $60)$.

$\mathrm{Na}$ disputa por sentidos e verdades sobre a educação, a governamentalidade neoliberal atua no sentido de suprimir e desqualificar a atuação dos professores pelo resultado das avaliações. Nessa direção, legitima a atuação de agentes e instituições externas, não raras vezes ligadas a grandes grupos empresariais e a agências internacionais de financiamento. A centralidade assumida pela avaliação no contexto das políticas educacionais neoliberais é tamanha que alguns autores chegam a falar em "pedagogia do exame" (LUCKESI, 2002) para caracterizar as práticas pedagógicas engendradas nesses contextos. Desse modo,

[...] busca-se reduzir e subordinar a prática do ensino-aprendizagem à exterioridade, a partir da adoção de regras e da utilização de um suporte material (livros, mídia institucional, parâmetros) que se quer prescritivo, estandardizado e, por isso mesmo, passível de ser classificado, mensurado e comparado, sempre com a finalidade de se atingir metas. (LOPES; LÓPEZ, 2010, p. 97).

A obsessão pelo alcance de metas faz parte da chamada cultura do desempenho, produtora de discursos que colocam em funcionamento regimes de verdade que "procuram fixar o que é um ensino de qualidade, como se deve desenvolver o ensinar, instituindo a cada qual dos

\footnotetext{
${ }^{4}$ Disponível em: <http://www.educacao.mg.gov.br>. Acesso em: 05 jun. 2015.

5 Ibidem.

${ }^{6}$ O Programa de Intervenção Pedagógica foi criado pela SEE/MG em 2008, com o objetivo de "atingir o nível recomendável de alfabetização e melhorar o desempenho dos alunos por meio de intervenções pedagógicas, capacitação e acompanhamento dos profissionais da educação". Disponível em: <http://www.educacao.mg.gov.br>. Acesso em: 30 jun. 2015.
} 
sujeitos sociais e pedagógicos novos papéis frente às demandas educacionais de nosso tempo" (ANADON, 2012, p. 7). O significado de ensinar se desloca para a produção de resultados quantificáveis, e o aprender é concebido como algo passível de mensuração em testes estandardizados. "Tais avaliações têm proposto uma aprendizagem que deve ser mensurada por meio das avaliações, mas que desconsidera [em parte] o contexto escolar, as peculiaridades dos alunos e sua evolução no processo de ensino-aprendizagem" (HYPÓLITO; IVO, 2013, p. 390).

Esse deslocamento de sentidos e a atribuição de novos significados a termos correntes no discurso educacional promovidos pela governamentalidade neoliberal vêm sendo analisados e criticados por diversos autores (GENTILLI, 1994; GENTILLI; SILVA, 1995). A heterogeneidade de discursos a demandar novos processos de gestão na educação nos permite compreender o contexto histórico que possibilita a emergência dos sistemas avaliativos em larga escala, bem como sua legitimação por boa parte dos sujeitos escolares e da sociedade de um modo mais amplo. Nesse sentido, devemos entender a conformação do dispositivo avaliativo mineiro como o resultado de um complexo jogo de forças, de uma disputa pela produção de sentidos e verdades acerca da educação e da avaliação, que tensiona e confronta diferentes perspectivas e interesses.

A noção de qualidade ilustra os deslocamentos e as ressignificações conceituais operados pela governamentalidade neoliberal. No contexto da cultura do desempenho e da performatividade que instaura, especialmente por meio das avaliações em larga escala, formas de operacionalização e racionalidade numéricas e economicistas, estas passam a dar conta de fenômenos como a repetência, a evasão e o desempenho de sujeitos e instituições escolares. Nesse sentido, pretende-se interpretar e visibilizar a qualidade do trabalho pedagógico por meio dos resultados que produz, no qual "as circunstâncias econômicas, políticas, sociais e culturais que permeiam o exercício da profissão docente, o ensino e as escolas são ignoradas ou então subsumidas a problemas de desempenho e esforço pessoal e profissional" (VOSS; GARCIA, 2014, p. 393). Cada vez mais, os resultados das avaliações vêm legitimando um tipo específico de verdade sobre a qualidade da educação, esvaziada de seu caráter social e atrelada a estatísticas e números.

\section{Como se estrutura e funciona o SIMAVE?}

Argumentamos que a avaliação tem se tornado um elemento central nas políticas educacionais contemporâneas, funcionando como um importante dispositivo de controle da conduta dos sujeitos escolares. Com base na noção de dispositivo, descrevemos nesta seção os três programas que compõem o SIMAVE, compreendendo-os assim como operadores materiais do poder, "isto é, as técnicas, as estratégias e as formas de assujeitamento [e subjetivação] utilizadas pelo poder" (REVEL, 2005, p. 39).

O PROEB, primeiro programa a ser criado no âmbito do SIMAVE, no ano de 2000, foi articulado por meio de uma parceria entre a SEE/MG e o Centro de Políticas Públicas e Avaliação da Educação (CAED), da Universidade Federal de Juiz de Fora (UFJF). Ele tem como propósito "verificar a eficiência e a qualidade do ensino no estado de Minas Gerais a partir dos resultados sobre o desempenho das escolas nas séries finais dos blocos de ensino" . As avaliações do PROEB são compostas por testes de múltipla escolha que aferem habilidades e competências dos alunos que se encontram no $5^{\circ}$ e $9^{\circ}$ ano do Ensino Fundamental e no $3^{\circ}$ ano do Ensino Médio, ou seja, abrangem os anos de escolaridade que finalizam cada etapa da Educação Básica. Escolas da rede estadual (em caráter obrigatório) e escolas municipais (em caráter facultativo)

${ }^{7}$ Disponível em: <http://www.simave.caedufjf.net>. Acesso em: 28 jul. 2015.

Práxis Educativa, Ponta Grossa, p. 714-735, v. 11, n. 3, set./dez. 2016 Disponível em: <http://www.revistas2.uepg.br/index.php/praxiseducativa > 
participam da avaliação. As questões/itens para esses testes avaliativos são elaboradas a partir de um conjunto de descritores elencados em Matrizes de Referência ${ }^{8}$ constituídas para as áreas de Língua Portuguesa e Matemática.

Já o PROALFA é realizado conjuntamente pelo Centro de Alfabetização, Leitura e Escrita (CEALE-UFMG) e pelo já citado CAED. Criado em 2005, esse programa surgiu para acompanhar o processo de aprendizagem dos alunos recém ingressados na rede pública de Minas Gerais, aos seis anos. O estado, antecipando-se ao governo federal na extensão da escolaridade obrigatória, instituiu o Ensino Fundamental de nove anos a partir de 2004, em cumprimento ao Decreto $\mathrm{n}^{\circ}$. 43.506, de 6 de outubro 2003. O PROALFA teve como alvo inicial os alunos da rede estadual que haviam começado o Ensino Fundamental em 2004, mas, em 2006, passou a integrar o SIMAVE e avaliar também alunos da rede estadual e municipal dos $2^{\circ}, 3^{\circ}$ e $4^{\circ}$ anos de escolaridade.

Por sua vez, o PAAE se difere dos demais por ser uma avaliação interna, dirigida exclusivamente às escolas estaduais. O PAAE foi criado em 2006 pelo Instituto Avaliar, organização da sociedade civil sem fins lucrativos, da qual fazem parte instituições do setor público e privado, dentre elas, o Banco Mundial. ${ }^{9}$ De acordo com Lúcia Mattos, uma das idealizadoras do Programa,

[...] com o [...] PAAE, a [...] SEEMG cria uma política de avaliação da aprendizagem que confere à escola a responsabilidade pela sua coordenação e pela gestão de seus resultados, mas atribui ao sistema estadual a responsabilidade de fornecer suporte didático para a sua operacionalização e para a definição dos referenciais de aprendizagem definidos como indicadores do que é básico para todos os alunos em Minas Gerais. ${ }^{10}$

De fato, cabe às escolas a tarefa de imprimir as provas, e a cada professor o lançamento dos resultados dos alunos na plataforma do Instituto Avaliar. Além disso, os próprios professores devem realizar a prova e lançar também suas respostas, promovendo uma espécie de "autoavaliação". As avaliações do Programa podem ser aplicadas até três vezes ao ano, de acordo com a demanda dos professores, por meio da chamada Avaliação Contínua. Entretanto, a Avaliação Diagnóstica (realizada no começo do ano letivo) e a Avaliação da Aprendizagem (realizada ao final do ano) são de caráter obrigatório. As questões que compõem o banco de dados do programa estão diretamente vinculadas aos tópicos do $\mathrm{CBC}$, sendo o objetivo central do programa "realizar diagnósticos progressivos da aprendizagem escolar em relação aos conteúdos do CBC" (MINAS GERAIS, 2009, p. 1). As avaliações do PAAE destinam-se aos estudantes do $1^{\circ}$ ano do Ensino Médio.

Esse dispositivo avaliativo que acabamos de delinear produz efeitos sobre as formas de organização da escola, seus currículos e suas práticas docentes, mas também sobre a subjetividade dos professores. Por meio desse dispositivo, o governo realiza

[...] uma certa manipulação das relações de força, [por meio] de uma intervenção racional e organizada nestas relações de força, seja para desenvolvê-las em determinada direção, seja para bloqueá-las, para estabilizá-las, utilizá-las, etc. O dispositivo, portanto, está sempre inscrito em um jogo de poder, estando sempre, no entanto, ligado a uma ou a configurações de saber que dele nascem, mas que igualmente o condicionam. (FOUCAULT, 1992, p. 139).

\footnotetext{
8 A elaboração das Matrizes baseia-se nos Conteúdos Básicos Comuns, nos Parâmetros Curriculares Nacionais e nas Diretrizes Nacionais de Educação. Disponível em: <http://www.simave.caedufff.net>. Acesso em: 06 jun. 2015.

${ }_{9}^{9}$ Disponível em: <http://www.institutoavaliar.org.br>. Acesso em: 30 jun. 2015.

${ }^{10}$ Disponível em: <http://www.anpae.org.br>. Acesso em: 30 jun. 2015.
}

Práxis Educativa, Ponta Grossa, p. 714-735, v. 11, n. 3, set./dez. 2016 Disponível em: <http://www.revistas2.uepg.br/index.php/praxiseducativa> 
Os dados, os gráficos, as tabelas, os números e os rankings articulados por esse dispositivo avaliativo produzem um conjunto de saberes que legitima práticas e discursos sobre a educação e o fazer docente. Podemos dizer, então, que a governamentalidade neoliberal mobiliza os saberes produzidos pelas avaliações para melhor controlar as condutas docentes. A próxima seção dedica-se à análise dos efeitos produzidos pela cultura do desempenho sobre a subjetividade docente.

\section{Os dispositivos e os processos de subjetivação docente}

É importante dizer que a governamentalidade neoliberal não inventa o procedimento avaliativo como forma de controle da conduta. Ao contrário, podemos afirmar que a avaliação é característica de uma série de instituições disciplinares surgidas na Modernidade, tais como o exército, a prisão, a fábrica, o hospital, a escola (FOUCAULT, 2008). Essas instituições, ao longo de seus percursos históricos, produziram verdades sobre os sujeitos que as habitam, pautadas em números, conceitos e atributos supostamente aferidos por meio de avaliações. O poder disciplinar em exercício nesses espaços "insere práticas na vida dos sujeitos: rotinas, exercícios, controle do tempo, hierarquias de saberes e habilidades" (DAMETTO, 2012, p. 58); simultaneamente, avalia o efeito desse conjunto de ações sobre o sujeito e cria prognósticos a serem alcançados.

O que a governamentalidade neoliberal traz de novo em relação aos procedimentos avaliativos em educação é a tentativa de atrelá-los ao governo de grandes populações, incorporando as práticas educacionais ao conjunto mais amplo da biopolítica. Partindo da avaliação de indivíduos (alunos, professores e gestores), a governamentalidade neoliberal traça metas e intervenções amplas que se dirigem à população escolar. As intervenções feitas com base nas avaliações têm a economia como grade de análise e são orientadas no sentido de promover a eficácia dos investimentos públicos. Os índices obtidos acabam por se transformar em medidores do "sucesso" das práticas pedagógicas, geralmente sem levar em conta o contexto no qual os dados são produzidos. De acordo com essa mentalidade, professores, alunos e escolas de "sucesso" são aqueles que conseguem alcançar as metas estabelecidas pelo governo, a despeito das condições objetivas onde as diferentes experiências educacionais ocorrem.

Especificamente, em Minas Gerais, os dispositivos curriculares e avaliativos põem em ação não apenas mecanismos de controle do currículo e das práticas avaliativas. Acionam também uma série de estratégias de governo das subjetividades docentes. Tais estratégias intentam conformar um tipo específico de conduta docente: são ações sobre as ações dos professores, que agem no sentido de alinhar suas práticas às metas para um bom desempenho. $\mathrm{O}$ bom desempenho é aquele que se aproxima com a maior eficácia dos indicadores estabelecidos pelo governo estadual, sendo por isso reconhecido e premiado.

Ensinar o que está prescrito torna-se importante por um conjunto de motivos que extrapola os limites colocados pelos objetivos do processo de aprendizagem. A importância dos CBC se coloca: aos alunos (que são vistos como tão bons quanto sua capacidade de apropriação dos conteúdos); aos professores (que são tão bons quanto sua capacidade de ensinar tais conteúdos, e devem ser premiados ou punidos pelo desempenho que os alunos apresentam); aos pais (que podem monitorar e controlar o trabalho das escolas, dos professores e dos alunos); e, finalmente, às próprias instituições escolares, cujos destinos e reconhecimento social dependem cada vez mais dos resultados obtidos nas avaliações externas (às quais o CBC serve como matriz de referência). 
Argumentamos que o ensinar (acionado pelo CBC) e o avaliar (acionado pelo SIMAVE) não são apenas atos de transformação da educação mineira. Ao produzir efeitos sobre professores, alunos, pais e escolas montam uma complexa rede de governo de Estado, dos outros e de si. No caso do professor, estamos assistindo à produção de subjetividades docentes atreladas aos ditames de especialistas, com forte base pragmática e utilitarista. É permitida ao professor uma pequena flexibilidade, ligada a procedimentos didáticos e metodológicos, mas conectada aos limites e às metas impostos pelo governo. Em suma, parece-nos, uma miragem de autonomia proposta pelo estado mineiro.

\begin{abstract}
Nesse profissionalismo não há muito espaço para um aumento de autonomia. O que tem ocorrido é que o controle sobre os fins sociais e políticos da Educação - as definições sobre currículo e programas, sobre o que e como ensinar - tem sido, cada vez mais, transferido das professoras para o controle dos gestores, dos políticos e dos interesses econômicos mais amplos. Muito embora os docentes sejam constantemente interpelados para uma associação colaborativa com os programas educativos oficiais nas escolas, para uma prática colaborativa e para uma autoadministração, os benefícios para a docência são muito ilusórios. (HYPÓLITO, 2010, p. 1346).
\end{abstract}

Nessa perspectiva, podemos afirmar que o currículo e os mecanismos avaliativos a eles atrelados funcionam como procedimentos de controle dos governos neoliberais sobre o trabalho docente que intentam produzir professores autogovernados, capazes de incorporar o conteúdo curricular obrigatório e as maneiras de avaliá-los, tornando-os aplicáveis e supostamente úteis em seus múltiplos espaços de atuação. O controle se dá por meio da responsabilização dos professores em relação à apropriação, efetivação e produção de resultados demandados pelo dispositivo curricular e identificáveis pelo dispositivo avaliativo. Uma nova forma de gestão e governo dos processos subjetivos é colocada em ação pela reforma curricular que diminui a autonomia e intensifica o trabalho docente. Estamos diante de uma forma de "autonomia imaginada, despersonalizada, uma docência de resultados confundida com profissionalismo, sobre o qual há poucas chances para o magistério negociar em meio a esses novos contratos do seu trabalho" (HYPÓLITO, 2010, p. 1346).

Os novos contratos de trabalho aos quais Hypólito se refere, em Minas Gerais se concretizam sob o nome de Acordo de Resultados. O Acordo efetiva a responsabilização das instituições escolares e dos professores pelo desempenho obtido diante das metas estabelecidas pelo governo, reforçando a cultura do desempenho na qual o currículo exerce um papel central:

[...] estabelecer os conhecimentos, as habilidades e competências a serem adquiridos pelos alunos na Educação Básica, bem como as metas a serem alcançadas pelo professor a cada ano, é uma condição indispensável para o sucesso de todo sistema escolar que pretenda oferecer serviços educacionais de qualidade à população. A definição dos [...] CBC para os anos finais do Ensino Fundamental e para o Ensino Médio constitui um passo importante no sentido de tornar a rede estadual de ensino de Minas num sistema de alto desempenho. (MINAS GERAIS, 2006a, p. 9).

Desde 2007, o governo vem pactuando acordos com diversas unidades administrativas por intermédio das Secretarias de Planejamento e de Gestão e da Fazenda, estando em jogo, além da bonificação por produtividade, a própria autonomia, e, no limite, a sobrevivência dessas instituições. Segundo a Secretaria de Estado de Planejamento e Gestão (SEPLAG), "o Acordo de Resultados é um instrumento de pactuação de resultados que estabelece, por meio de indicadores 
e metas, quais os compromissos devem ser entregues pelos órgãos e entidades do Poder Executivo Estadual, em linha com os objetivos expressos na agenda de governo"11.

Os resultados trazidos por essas avaliações permitem ou não a professores e a instituições receberem um "prêmio por produtividade", que "é um mecanismo de bonificação para os servidores que integram as equipes dos órgãos/entidades que assinaram o Acordo. O prêmio não é uma complementação salarial, mas sim, uma maneira de incentivar, por mérito, os servidores que conseguiram alcançar resultados satisfatórios nas metas pactuadas" ". Baseia-se no pressuposto de que "o contratante tem clareza dos resultados que pretende, e que o incentivo a ser pago ao contratado é determinante para motivá-lo nesta direção para evitar comportamentos destoantes - assegurados os meios e controles necessários" (MINAS GERAIS, 2013, p. 67). "Parece que a figura do professor, nesse contexto, fica esmaecida, enquanto os índices adquirem centralidade" (TRAVERSINI; BELLO, 2009, p. 147).

Esse dispositivo avaliativo também pode ser pensado como um incentivador, um potencializador da cultura do desempenho que o governo mineiro pretende difundir entre seus servidores. De acordo com a SEPLAG, no cerne da reforma da gestão do estado está o desejo de "auxiliar na implementação de uma cultura voltada para resultados, estimulando, valorizando e destacando servidores, dirigentes e órgãos ou entidades que cumpram suas metas e atinjam os resultados previstos" ${ }^{\prime 3}$. Pensamos que a performatividade incitada pelas políticas empreendidas pelo governo mineiro produz novos papéis e novas subjetividades docentes, à medida que "os professores são transformados em produtores/fornecedores, empresários da Educação e administradores, e ficam sujeitos à avaliação e análise periódicas e a comparações de desempenho" (BALL, 2005, p. 547). Em contextos marcados pelo imperativo da competição, da eficiência e da produtividade emergem novos sistemas éticos, pautados pelo pragmatismo e interesses de cada instituição. As relações travadas pelos diferentes sujeitos escolares são desafiadas e deslocadas pelas práticas de performatividade: no bojo da cultura do desempenho, são todos vistos como produtores das metas traçadas pelas diferentes instâncias governamentais.

De acordo com Ball, também a gestão tem sido um mecanismo chave nas reformas políticas educacionais contemporâneas. A gestão "desempenha um papel crucial no desgaste dos regimes ético-profissionais nas escolas e sua substituição por regimes empresariais e competitivos. Enquanto os mercados trabalham de fora para dentro, a gestão funciona de dentro para fora" (BALL, 2001, p. 108). Temos um novo herói no paradigma neoliberal: ele é o gestor. A ele cabe difundir e incutir nos trabalhadores o sentimento de responsabilidade e comprometimento, controlando e conformando a subjetividade dos professores. Deles é exigida a qualidade e a excelência, aferidas constantemente por meio de técnicas de vigilância e automonitoramento. De acordo com a Revista do $\operatorname{Gestor}^{14}$ (2011, p. 6), publicada pela SEE/MG, "o gestor, como agente impulsionador de mudanças e figura chave para estruturação de uma escola verdadeiramente democrática, ganha importante destaque na busca por uma educação de qualidade, capaz de promover equidade educacional e diminuir as desigualdades sociais".

\footnotetext{
${ }^{11}$ Disponível em:

<http://www.planejamento.mg.gov.br/images/documentos/gestao_pessoas_politicas_desenvolvimento/trilhas_do desenvolvimento/Competencias_tecnicas/AGEIs/251\%20-

$\% 20 \mathrm{O} \% 20$ Acordo $\% 20 \mathrm{de} \% 20$ Resultados $\% 20$ no $\% 20$ Governo $\% 20 \mathrm{de} \% 20$ Minas $\% 20$ Gerais.pdf $>$. Acesso em: 07 jan. 2015.

12 Ibidem.

13 Ibidem.

${ }^{14}$ Disponível em: <http:/ /www.simave.caedufff.net>. Acesso em: 01 jul. 2015.
}

Práxis Educativa, Ponta Grossa, p. 714-735, v. 11, n. 3, set./dez. 2016 Disponível em: <http://www.revistas2.uepg.br/index.php/praxiseducativa $>$ 
"Assim, o trabalho do gestor envolve o instilar da atitude e da cultura segundo a qual o trabalhador se sente, ele próprio, responsável e ao mesmo tempo comprometido ou pessoalmente empenhado na organização" (BALL, 2002, p. 8). A supervalorização da gerência promovida pelo neoliberalismo pode ser compreendida como uma tecnologia política, que tem como objetivo vincular a atuação dos gestores aos mecanismos reguladores e avaliadores do Estado a fim de potencializar os processos de inculcação e adesão exigidos pela reforma.

\section{Conclusão}

As tecnologias políticas neoliberais contribuem para a conformação da cultura da performatividade, na qual "o desempenho (de sujeitos individuais ou organizações) funciona como medida de produtividade ou resultado, ou exposição de 'qualidade', ou 'momentos' de produção ou inspeção" (BALL, 2001, p. 109). No ponto alto dessa cultura estão os momentos de balanço anual, a produção de relatórios escritos e solicitações de promoção, as avaliações por colegas. "Mais do que somente uma estrutura de vigilância, há, na verdade, um fluxo contínuo de performatividades contínuas e importantes, isto é, um espetáculo” (BALL, 2001, p. 110).

O conjunto de elementos forjados pela governamentalidade neoliberal tem resultados diversos na subjetividade e na prática docentes. A crescente individualização das relações profissionais se faz acompanhar pelo aumento do trabalho burocrático e da vigilância sobre o trabalho docente e os produtos finais da educação. Ao mesmo tempo, distanciam-se as expectativas do pessoal técnico e da equipe docente, confrontados por objetivos e valores muitas vezes antagônicos. Essas novas tecnologias políticas são "uma mescla de elementos físicos, textuais e morais" (BALL, 2001, p. 112). Como novas formas de regulação, baseadas no desempenho, elas afetam diferentes dimensões das relações institucionais, estimulando novas relações entre os professores e entre estes e os alunos; estes e os pais, estabelecendo seus valores como profissionais proporcionalmente à contribuição que dão à performatividade de sua unidade. Conforme Ball (2002, p. 11), "as classificações e graduações, introduzidas nas competições entre os grupos, podem criar sentimentos individuais de orgulho, culpa, vergonha e inveja". Nesse sentido, "a performatividade atinge profundamente a percepção do eu e de nosso próprio valor. Coloca em pauta uma dimensão emocional, apesar da aparência de racionalidade e objetividade" (BALL, 2005, p. 550).

Também as relações professor-aluno são modificadas nesse contexto, já que os professores passam a olhar para os próprios alunos como produtores (ou não) do desempenho "excelente" que a escola deve buscar. E importante perceber que não se trata simplesmente de coisas que nos fazem. Trata-se também e principalmente de coisas que fazemos a nós mesmos e aos outros, da nossa constituição em tipos específicos de seres e, nesse caso, formas específicas de ser professor (BALL, 2005). Estamos diante de uma nova forma de governamentalidade que busca "utilizar mais táticas do que leis, ou utilizar ao máximo as leis como táticas. Fazer, por vários meios, que determinados fins sejam atingidos" (FOUCAULT, 1992, p. 284). Não mais a norma como interdição, como proibição que se coloca de modo externo e violento ao sujeito: o neoliberalismo nos coloca em um jogo de governo que intenta fazer com que os sujeitos desejem a regra, internalizem determinadas condutas e sejam capazes de se autogovernar. Devemos pensar os modelos de avaliação externas e estandardizadas como exercícios de poder:

[...] poder produtivo, multifacetado e relacional. Avaliações colocam em funcionamento um poder que induz, incita e fabrica os sujeitos que avalia de modo muito particular. As práticas avaliativas modificam comportamentos dos indivíduos tornando-os sujeitos autoconfiantes e autorresponsáveis pela melhoria da qualidade da educação. (ANADON, 2012, p. 13).

Práxis Educativa, Ponta Grossa, p. 714-735, v. 11, n. 3, set./dez. 2016 Disponível em: < http://www.revistas2.uepg.br/index.php/praxiseducativa> 
Se entendermos os processos de subjetivação como um conjunto de práticas e discursos que transformam os seres humanos em sujeitos - assujeitados, objetivados e afeitos ao seu próprio controle - podemos afirmar que a governamentalidade neoliberal aciona um jogo de poder que intenta conformar um tipo específico de sujeito docente, orientado pelos preceitos da utilidade, da eficiência e da competitividade. Se, "no curso de sua história, os homens jamais cessaram de se construir, isto é, de deslocar continuamente sua subjetividade, de se constituir numa série infinita e múltipla de subjetividades diferentes" (FOUCAULT, 1995 apud REVEL, 2005 , p. 85), como resistir aos mecanismos de poder que não cessam de tentar capturar e conduzir essa constituição?

Diante dessa pergunta, devemos reconhecer que no interior das escolas se instalam novas disputas pelos significados e sentidos do que é ensinar e de quais são os conteúdos, os métodos, os objetivos e as formas de avaliação pertinentes ao fazer educacional. Embora o discurso normalizador de origem estatal se pretenda hegemônico, as políticas curriculares e avaliativas são reorientadas por estratégias locais, nas várias instâncias subsequentes à sua produção. Ainda que a implementação de currículos obrigatórios e de instrumentos sistemáticos de avaliação externa se traduza na sobrecarga de tarefas e no acúmulo de responsabilidades para os sujeitos docentes, devemos considerar que as relações que se constituem em âmbito escolar também podem caminhar em busca de aberturas e possibilidades de escape ao prescrito, de mais prazer e solidariedade (MANCEBO, 2010).

Especialmente no que se refere às artes neoliberais de governar a educação, isso envolveria "resistir, evitar, contrariar ou se opor não apenas às formas pelas quais nós temos sido encorajados a ser pouco mais do que sujeitos auto-interessados da escolha racional" (HAMMAN, 2012, p. 131), mas também às maneiras pelas quais nossas escolas, comunidades e formas de participação política têm sido reformadas no intuito de estimular a produção do docente como um prestador de serviço. Querem-nos professores pragmáticos, individualistas e empresários de nossas trajetórias profissionais; a resistência aos mecanismos de poder - que agem para nos conformar nesse tipo de sujeito - deve fortalecer os espaços democráticos de diálogo, bem como promover a capilarização das tomadas de decisão no que se refere ao estabelecimento de prioridades e objetivos para o sistema educacional público.

Concluímos reforçando o argumento de que a governamentalidade neoliberal atua sobre os sujeitos de modo a conduzi-los a se comportar de determinadas maneiras no mundo. Focamos os processos de subjetivação docente postos em ação nesse processo. Essa foi a nossa escolha, nosso recorte, nosso alvo. Muitos outros sujeitos da educação (alunos, gestores, inspetores, pais) têm sido "enformados" economicamente pelas técnicas e estratégias neoliberais, e compreender os processos de constituição desses sujeitos é também de extrema importância. Foucault (1984, p. 44) nos alerta que "a escolha ético-política que nós temos de fazer diariamente é determinar qual é o principal perigo. [...]. Não que tudo seja ruim, mas que tudo é perigoso. [...]. Se tudo é perigoso, então sempre temos algo a fazer". Como professores que somos, cotidianamente atravessados pelos imperativos da performatividade, do gerencialismo e do mercado que orientam as políticas educacionais no Brasil nas últimas décadas, reforçamos aqui a importância de analisarmos os discursos, os procedimentos e as tecnologias que intentam nos transformar em determinados tipos de docentes.

Por isso, pela urgência das questões que o presente nos coloca, pensamos que é preciso construir respostas novas aos desafios educacionais do nosso tempo. "Um tempo que demanda de nós não apenas a compreensão do mundo em que vivemos, mas, sobretudo, a criação de instantes de suspensão dos sentidos já criados e a abertura de possibilidades de sua ressignificação" (MEYER; PARAÍSO, 2012, p. 21). Se estamos nos transformando em tipos 
específicos de professores nos contextos neoliberais (BALL, 2005), argumentamos que é cada vez mais importante "estranhar" essa nova governamentalidade hegemônica, inquiri-la, questioná-la, desafiá-la. Ao aceitarmos como pressuposto que a verdade é uma invenção, uma construção, sabemos que, ao elaborar nossos objetos, estamos adentrando o território em disputa dos "regimes de verdade" (FOUCAULT, 1984). Porém não pretendemos dar uma resposta cabal e definitiva às questões que apresentamos. Acreditamos que as formas possíveis de resistência se conformarão no âmbito de cada município, de cada escola, em cada sala de aula, nas práticas de cada professor. Ainda que os mecanismos de poder se pretendam absolutos e totalitários, o campo de ação do sujeito sempre permite rotas de fuga, alternativas, escapes específicos ao contexto.

Queremos potencializar e instrumentalizar tais lutas docentes com nossas palavras. Desejamos fazeres educacionais mais humanos, que possibilitem aos professores a reinvenção do mundo fora dos domínios do utilitarismo e da competitividade, alargando as fronteiras do pensamento e da experiência. Que as ideias que desenvolvemos ajudem a desnaturalizar os discursos naturalizados que pretendem nos constranger, submetendo-os a uma crítica atenta e permanente.

\section{Referências}

ALTMANN, H. Influências do Banco Mundial no projeto educacional brasileiro. Educação e Pesquisa, v. 28, n. 1, p. 77-89, jan./jun. 2002. DOI 10.1590/S1517-97022002000100005

ANADON, S. B. Prova Brasil: uma estratégia de governamentalidade. 2012. 172 f. Tese (Doutorado em Educação) - Universidade Federal de Pelotas (UFPEL), Pelotas, 2012.

BALL, S. J. Cidadania global, consumo e política educacional. In: SILVA, L. H. (Org.). A escola cidadã no contexto da globalização. Petrópolis: Vozes, 1998, p. 121-137.

BALL, S. J. Diretrizes políticas globais e relações políticas locais em Educação. Currículo sem Fronteiras, v. 1, n. 2, p. 99-116, jul./dez. 2001.

BALL, S. J. Reformar escolas / reformar professores e os terrores da performatividade. Revista Portuguesa de Educação, v. 15, n. 2, p. 3-23, 2002.

BALL, S. J. Profissionalismo, gerencialismo e performatividade. Cadernos de Pesquisa, São Paulo, v. 35, n. 126, p. 539-564, set./dez. 2005. DOI: 10.1590/S0100-15742005000300002

DAMETTO, J. Notas preliminares sobre a avaliação em larga escala e sua incidência sobre a subjetividade docente. Revista Espaço Acadêmico, Maringá, v. 12, n. 138, p. 56-63, nov. 2012.

DARLING-HAMMOND, L.; ASCHER, C. Construindo sistemas de controle em Escolas Urbanas. Estudos em Avaliação Educacional, São Paulo, v. 17, n. 35, set./dez. 2006. DOI: 10.18222/eae173520062107

DECLARAÇÃO MUNDIAL SOBRE EDUCAÇÃO PARA TODOS. Conferência Mundial de Educação para Todos, 1990, Jomtien. Brasília: Unicef, 1991.

FOUCAULT, M. História da sexualidade. 2. ed. Rio de Janeiro: Edições Graal, 1984. 
FOUCAULT, M. Microfísica do poder. Rio de Janeiro: Graal, 1992.

FOUCAULT, M. O sujeito e o poder. In: DREYFRUS, H.; RABINOW, P. (Orgs.). Michel Foucault: uma trajetória filosófica para além do estruturalismo e da hermenêutica. Rio de Janeiro: Forense, 1995.

FOUCAULT, M. Em defesa da sociedade. São Paulo: Martins Fontes, 2000.

FOUCAULT, M. O nascimento da biopolítica. São Paulo: Livraria Martins Fontes, 2008.

FOUCAULT, M. A verdade e as formas jurídicas. Rio de Janeiro: Nau, 2009.

GENTILLI, P. Neoliberalismo e Educação: manual do usuário. In: GENTILLI, P.; SILVA, T. T. (Orgs.). Escola S.A. Brasília: CNTE, 1994.

GENTILI, P.; SILVA, T. T. (Orgs.). Neoliberalismo, qualidade total e educação. Petrópolis: Vozes, 1995.

HAMMAN, T. H. Neoliberalismo, governamentalidade e ética. Ecopolítica, v. 3, p. 99-133, 2012.

HYPÓliTO, A. M. Políticas curriculares, estado e regulação. Educação \& Sociedade, Campinas, v. 31, n. 113, p. 1337-1354, out./dez. 2010. DOI: 10.1590/S0101-73302010000400015

HYPÓliTO, A. M.; IVO, A. A. Políticas curriculares e sistemas de avaliação: efeitos sobre o currículo. E-curriculum, São Paulo, n. 11, v. 2, p. 376-392, ago. 2013.

HYPÓLITO, A. M.; VIEIRA, J. S.; PIZZI, L. C. V. Reestruturação curricular e autointensificação do trabalho docente. Currículo sem Fronteiras, v. 9, n. 2, p. 100-112, jul./dez. 2009.

LARROSA, J. Tecnologias do eu e a Educação. In: SILVA, T. T. (Org.). O sujeito da Educação: estudos foucaultianos. Petrópolis: Vozes, 1994, p. 35-86.

LOPES, A. C. Políticas curriculares: continuidade ou mudança de rumos? Revista Brasileira de Educação, Rio de Janeiro, n. 26, p. 109-118, maio/ago. 2004. DOI: 10.1590/S141324782004000200009

LOPES, A. C.; LÓPEZ, S. B. A performatividade nas políticas de currículo: o caso do ENEM. Educação em Revista, Belo Horizonte, v. 26, n. 1, p. 89-110, abr. 2010. DOI: 10.1590/S010246982010000100005

LOPES, A. C.; MACEDO, E. Teorias de currículo. São Paulo: Cortez, 2011.

LUCKESI, C. Avaliação da aprendizagem escolar: estudos e proposições. São Paulo: Cortez, 2002.

MANCEBO, D. Subjetividade docente. In: OLIVEIRA, D. A.; DUARTE, A. M. C.; VIEIRA, L. M. F. (Orgs.). Dicionário: trabalho, profissão e condição docente. Belo Horizonte: UFMG/Faculdade de Educação, 2010. 
MEYER, D. S. M.; PARAÍSO, M. A. Metodologias de pesquisas pós-críticas em educação. Belo Horizonte: Mazza Edições, 2012.

MINAS GERAIS. Conteúdos básicos comuns/artes/ensino fundamental e médio. Belo Horizonte: Secretaria de Estado de Educação de Minas Gerais, 2006a.

MINAS GERAIS. Conteúdos básicos comuns/ciências/ensino fundamental. Belo Horizonte: Secretaria de Estado de Educação de Minas Gerais, 2006b.

MINAS GERAIS. Novo plano curricular do ensino médio. Belo Horizonte: Secretaria de Estado de Educação de Minas Gerais, 2007.

MINAS GERAIS, Avaliação continuada: apropriação e utilização dos resultados. Juiz de Fora: FADEPE, 2009.

MINAS GERAIS. Do choque de gestão à gestão para a cidadania: 10 anos de desenvolvimento em Minas Gerais. Belo Horizonte: Gráfica Ipiranga, 2013.

MOREIRA, A. F. Os parâmetros curriculares nacionais em questão. Educação e Realidade, Porto Alegre, v. 21, n. 1, p. 9-23, jan./jun. 1996.

PARAÍSO, M. A.; SANTOS, L. L. C. P. O currículo como campo de luta. Presença Pedagógica, v. 2, n. 7, p. 32-39, jan./fev. 1996.

PETERS, M.; MARSHALL, J.; FITZSIMONS, P. Gerencialismo e política educacional em um contexto global. In: BURBULES, N.; TORRES, C. A. (Orgs.). Globalização e Educação. Porto Alegre: ArtMed, 2004.

RAJCHMAN, J. Foucault e a liberdade da Filosofia. Rio de Janeiro: Jorge Zahar Editor, 1987.

RABINOW, P.; ROSE, N. O conceito de biopoder hoje. Política e Trabalho, n. 4, p. 27-57, abr. 2006.

REVEL, J. Foucault: conceitos essenciais. São Carlos: Claraluz, 2005.

TERIGI, F. Notas para uma genealogia do currículo escolar. Educação e Realidade, v. 21, n. 1, p. 159-186, jan./jun. 1996.

TORRES, R. M. Melhorar a qualidade da educação básica? As estratégias do banco mundial. In: TOMMASI, L. De; WARDE, J. M.; HADDAD, S. (Orgs.) O Banco mundial e as políticas educacionais. São Paulo: Cortez, 1998

TRAVERSINI; C. S.; BELLO, S. E. L. O numerável, o mensurável e o auditável: estatística como tecnologia para governar. Educação e Realidade, Porto Alegre, v. 34, n. 2, p. 135-152, maio/ago. 2009.

VOSS, D. M. S.; GARCIA, M. M. A. O discurso da qualidade da Educação e governo da conduta docente. Educação e Realidade, Porto Alegre, v. 39, n. 2, p. 391-412, abr./jun. 2014. 
WERLE, F. O. C. Políticas de avaliação em larga escala na educação básica: do controle de resultados à intervenção nos processos de operacionalização do ensino. Ensaio, Rio de Janeiro, v. 19, n. 73, p. 769-792, out./dez. 2011. DOI: 10.1590/S0104-40362011000500003

Recebido em 15/02/2016

Aceito em 26/04/2016

Práxis Educativa, Ponta Grossa, p. 714-735, v. 11, n. 3, set./dez. 2016 Disponível em: <http://www.revistas2.uepg.br/index.php/praxiseducativa> 